\title{
HUBUNGAN PERSEPSI PASIEN PADA PELAYANAN KEPERAWATAN DENGAN KEPUASAN PASIEN DI RUANG PAVILIUN RSUD JEND. AHMAD YANI METRO
}

\author{
Nuri Luthfiatil Fitri \\ Akper Dharma Wacana Metro \\ Jl.Kenanga no.3 16.C Mulyojati Kota Metro
}

\begin{abstract}
Abstrak
Latar belakang: Kepuasan pasien adalah indikator pertama dari standar suatu rumah sakit dan merupakan suatu ukuran mutu pelayanan. Kepuasan pasien yang rendah akan berdampak terhadap jumlah kunjungan dirumah sakit. Sikap perawat terhadap pasien juga akan berdampak terhadap kepuasan pasien dimana kebutuhan pasien dari waktu ke waktu akan meningkat, begitu pula tuntutannya akan mutu pelayanan yang diberikan. Tujuan penelitian ini adalah untuk mengetahui hubungan persepsi pasien pada pelayanan keperawatan dengan kepuasan pasien di Ruang Paviliun RSUD Jend. Ahmad Yani Metro tahun 2014.
\end{abstract}

Metode: Jenis penelitian kuantitatif, rancangan survey analitik menggunakan pendekatan cross sectional. Populasi dalam penelitian ini adalah pasien RSUD Jend. Ahmad Yani Metro sebanyak 64 dan seluruhnya dijadikan sampel. Analisis dalam penelitian ini menggunakan uji chi square.

Hasil: Hasil penelitian didapatkan sebesar 85,94\% pasien memiliki persepsi dalam kategori baik, dan 68,8\% memiliki tingkat kepuasan dalam kategori puas. Hasil analisis menunjukkan terdapat hubungan bermakna antara persepsi pasien pada pelayanan keperawatan dengan kepuasan pasien ( $p$-value $=0,022<\alpha$ 0,05; OR 5,857 (CI;95\%: 1,290-26,590).

Kesimpulan: Persepsi dan tingkat kepuasan pasien dapat memberikan gambaran bagaimana pelayanan keperawatan yang dilakukan oleh perawat. Oleh karena itu, Seiring dengan berjalannya waktu dan bertambahnya kebutuhan pelayanan kesehatan menuntut perawat saat ini memiliki pengetahuan dan keterampilan di berbagai bidang. Saat ini perawat memiliki peran yang lebih luas dengan penekanan pada peningkatan kesehatan dan pencegahan penyakit, juga memandang klien secara komprehensif.

Kata Kunci : Persepsi, Tingkat Kepuasan 


\section{Pendahuluan}

Era globalisasi merupakan suatu era baru yang akan membawa berbagai perubahan dibidang kehidupan. Salah satunya yaitu perubahan dibidang kesehatan. Pasar bebas berakibat pada bertambahnya jumlah rumah sakit dan tingginya kompetisi dibidang kesehatan dalam memberikan pelayanan kesehatan, sehingga menuntut penyedia jasa pelayanan kesehatan seperti rumah sakit untuk meningkatkan kualitas mutu pelayanan yang lebih baik. Disamping itu tingginya tingkat pengetahuan masyarakat akan mutu pelayanan kesehatan sebagai dampak dari teknologi informasi, dan banyaknya fasilitas kesehatan swasta yang menjanjikan akan pelayanan prima, mengakibatkan tuntutan terhadap peningkatan mutu pelayanan dan profesionalisme para penyedia layanan kesehatan ${ }^{1}$.

Pelayanan keperawatan di rumah sakit merupakan bagian yang tidak dapat dipisahkan dari pelayanan kesehatan secara keseluruhan, bahkan sebagai salah satu faktor penentu bagi mutu pelayanan dan citra rumah sakit di mata masyarakat. Berdasarkan itu, maka pelayanan keperawatan secara organisatoris, administrasi dan teknik tidak dapat dipisahkan dari pelayanan rumah sakit pada umumnya. Pelayanan keperawatan membutuhkan ketelitian sebab mengemban misi mengatur sumber daya manusia yang terbesar jumlahnya di rumah sakit $^{2}$.

Mutu pelayanan menunjukkan tingkat kesempurnaan pelayanan kesehatan yang dapat menimbulkan kepuasan karena telah sesuai kode etik dan standar pelayanan professional. Bagian integral dari standar pelayanan profesional kesehatan di rumah sakit salah satunya adalah pelayanan keperawatan. Keperawatan sering disebut sebagai ujung tombak dari pelayanan yang ada di rumah sakit, pelaksana asuhan keperawatan, selain itu perawat selama 24 jam berada didekat pasien, disebutkan juga bahwa $70 \%$ tenaga kesehatan di rumah sakit adalah perawat, sehingga perawat memegang peranan yang cukup dominan dalam rangka memberikan kepuasan kepada pelanggan atau pasien. Pelayananan keperawatan bersifat komperehensif, mencakup pelayanan bio-psikososio-kultural dan spiritual. Dalam kepuasan hal terpenting adalah persepsi pelanggan, bukan halhal yang aktual seperti yang dipikirkan produsen atau pemberi jasa. Sehingga masyarakat sering menilai baik buruknya pelayanan di instalasi rawat inap tergantung bagaimana kinerja dari perawat ${ }^{3}$.

Kepuasan pasien adalah indikator pertama dari standar suatu rumah sakit dan merupakan suatu ukuran mutu pelayanan. Kepuasan pasien yang rendah akan berdampak terhadap jumlah kunjungan dirumah sakit. Sikap perawat terhadap pasien juga akan berdampak terhadap kepuasan pasien dimana kebutuhan pasien dari waktu ke waktu akan meningkat, begitu pula tuntutannya akan mutu pelayanan yang diberikan ${ }^{3}$.

RSUD Jend A. Yani merupakan Instansi Daerah dari Pemerintah Kota Metro yang dibentuk berdasarkan Perda Kota Metro Nomor 03 tahun 2003 adalah unsur pelaksana daerah yang berada di bawah dan bertanggung jawab langsung kepada Walikota Metro dan diperbaharui dengan Perda Kota Metro No. 7 Tahun 2008 bahwa RSUD Jend. A. Yani merupakan Lembaga Teknis Daerah namun pada tanggal 30 Desember 2010 dengan Peraturan Walikota Metro NO : 343/KPTS/RSU/2010, RSUD Jend. A. Yani ditetapkan sebagai Instansi Pemerintah Kota Metro yang menerapkan PPKBLUD. Berdasarkan Keputusan Walikota Metro tentang Tugas Pokok, tugas pokok RSUD Jend, A. Yani adalah melaksanakan urusan rumah tangga Pemerintah Kota Metro dalam bidang pelayanan kesehatan masyarakat dan pelayanan kesehatan rujukan dan melaksanakan tugas-tugas pengobatan, pemeriksaan kesehatan, perawatan, bimbingan dan latihan, pemulihan kesehatan, rehabilitasi kesehatan dan semua pelayanan dibidang kesehatan.

Dalam melaksanakan tugas pokok, RSUD Jend A. Yani menyelenggarakan fungsi: 1) Melaksanakan pelayanan medis dan penunjang medis yang sebaiknya kepada masyarakat, 2) Memberikan pelayanan perawatan dan pemulihan kesehatan secara paripurna kepada masyarakat, 3) Memberikan pelayanan penyuluhan kesehatan, pendidikan dan latihan bagi masyarakat, serta penelitian-penelitian guna peningkatan pelayanan.

Berdasarkan uraian di atas, maka penulis tertarik untuk melakukan penelitian tentang hubungan persepsi pasien pada pelayanan keperawatan dengan kepuasan pasien di Ruang Paviliun RSUD Jend. Ahmad Yani Metro tahun 2014. 


\section{Metode Penelitian}

Jenis penelitian ini adalah penelitian kuantitatif yaitu penelitian yang datanya berupa angka-angka (skore, nilai) atau pernyataan yang diangkakan dan dianalisis dengan analisis statistik. Rancangan penelitian menggunakan survey analitik dengan pendekatan cross sectional.

Populasi dalam penelitian ini adalah seluruh pasien yang ada di Ruang Paviliun RSUD Jend. Ahmad Yani Metro pada bulan Februari tahun 2014 yang berjumlah 64 orang. Seluruh jumlah populasi akan dijadikan sampel (total sampling). Teknik pengambilan sampel dalam penelitian ini menggunakan teknik accidental sampling.

Metode pengumpulan data yang digunakan pada variabel independen dan dependen yaitu angket berupa kuesioner yang berisi 20 pernyataan, skor pernyataan terdiri dari 4 (empat) kategori yaitu baik/puas $=4$, cukup baik/cukup puas $=3$, kurang baik/kurang puas $=$ 2 dan tidak baik/tidak puas $=1$. Pertanyaan yang disusun dalam kuesioner penelitian ini dirancang oleh peneliti berdasarkan standar uraian tugas perawat pelaksana di ruang rawat inap.

\section{Hasil Penelitian}

Berdasarkan hasil observasi terhadap 64 responden, maka didapatkan distribusi frekuensi pada setiap variabel sebagaimana diuraikan di bawah ini:

Tabel 1

Distribusi Frekuensi Persepsi Pasien Pada Pelayanan Keperawatan di RSUD Jend. Ahmad Yani Metro

\begin{tabular}{cccc}
\hline No & $\begin{array}{c}\text { Persepsi } \\
\text { Pasien }\end{array}$ & Frekuensi & Persentase (\%) \\
\hline 1 & Baik & 55 & 85,9 \\
2 & Kurang baik & 9 & 14,1 \\
\hline & $\Sigma$ & $\mathbf{6 4}$ & $\mathbf{1 0 0 , 0}$ \\
\hline
\end{tabular}

Tabel 2

Distribusi Frekuensi Kepuasan Pasien Pada Pelayanan Keperawatan di RSUD Jend. Ahmad Yani Metro

\begin{tabular}{cccc}
\hline No & $\begin{array}{c}\text { Kepuasan } \\
\text { Pasien }\end{array}$ & Frekuensi & Persentase (\%) \\
\hline 1 & Puas & 44 & 68,75 \\
2 & Kurang puas & 20 & 31,25 \\
\hline & $\Sigma$ & $\mathbf{6 4}$ & $\mathbf{1 0 0 , 0}$ \\
\hline
\end{tabular}

Tabel 3

Hubungan Persepsi Pasien Pada Pelayanan Keperawatan Dengan Kepuasan Pasien di Ruang Paviliun RSUD Jend. Ahmad Yani Metro

\begin{tabular}{|c|c|c|c|c|c|c|c|c|}
\hline \multirow{3}{*}{$\begin{array}{l}\mathrm{N} \\
\mathrm{o}\end{array}$} & \multirow{3}{*}{$\begin{array}{c}\text { Persepsi } \\
\text { Pasien }\end{array}$} & \multicolumn{3}{|c|}{$\begin{array}{c}\text { Kepuasan } \\
\text { Pasien }\end{array}$} & \multirow{3}{*}{\multicolumn{2}{|c|}{$\sum \%$}} & \multirow{3}{*}{$\begin{array}{c}p- \\
\text { valu } \\
e\end{array}$} & \multirow{3}{*}{$\begin{array}{c}O R \\
(95 \% \\
C I)\end{array}$} \\
\hline & & Puas & \multicolumn{2}{|c|}{$\begin{array}{c}\text { Kuran } \\
\text { Puas }\end{array}$} & & & & \\
\hline & & $\begin{array}{ll}n & \%\end{array}$ & $n$ & $\%$ & & & & \\
\hline \multirow[b]{4}{*}{2} & & 74 & & 25, & 5 & 10 & \multirow{5}{*}{$\begin{array}{c}0,02 \\
2\end{array}$} & \multirow{6}{*}{$\begin{array}{c}5,857 \\
(1,290- \\
26,590 \\
\quad)\end{array}$} \\
\hline & & $41 \quad 5$ & 14 & 45 & 5 & 0 & & \\
\hline & Kurang & 33 & & 66 & & 10 & & \\
\hline & Baik & 33 & 6 & 7 & 9 & 0 & & \\
\hline & & 68 & & 31, & 6 & 10 & & \\
\hline & $\sum$ & $44 \quad 8$ & 20 & 3 & 4 & 0 & & \\
\hline
\end{tabular}

\section{Pembahasan}

Kwalitas atau mutu menurut Goetsh dan davis ${ }^{4}$ merupakan suatu kondisi dinamis yang berhubungan dengan produk, jasa, manusia, proses dan lingkungan yang memenuhi atau melebihi harapan.Menurut levelock dan wright ${ }^{5}$ kwalitas pelayanan dapat diukur dengan membandingkan persepsi antara pelayanan yang diharapkan dengan pelayanan yang diterima dan dirasakan oleh pelanggan.

Kelengkapan sarana dan prasarana juga perlu diperhatikan, mengingat hal tersebut akan mempengaruhi kepuasan konsumen. Menurut Kotler, ${ }^{6}$ salah satu upaya yang dilakukan manajemen perusahaan terutama yang berhubungan dengan kepuasan konsumen yaitu dengan memberikan fasilitas sebaik-baiknya demi menarik dan mempertahankan pelanggan. Fasilitas merupakan sarana maupun prasarana yang penting dalam usaha meningkatkan kepuasan seperti memberi kemudahan serta memenuhi kebutuhan dan kenyamanan bagi pengguna jasa.

Infrastruktur dan fasilitas penunjang rawat inap akan menentukan kwalitas layanan dan akhirnya berdampak terhadap kepuasan dan loyalitas pasien rawat inap. Beberapa hasil penelitian yang telah dilakukan oleh Boller et al, Andeleeb, Baltussen et al dan Doung et al, ${ }^{7-10}$ menyatkan bahw fasilitas medis merupakan bagian dimensi kwalitas layanan rawat inap. 


\section{Persepsi Pasien Pada Pelayanan Keperawatan}

Berdasarkan hasil pengumpulan dan pengolahan data dapat diketahui bahwa dari 64 responden, sebagian besar memiliki persepsi dalam kategori baik pada pelayanan keperawatan yaitu terdapat 55 orang $(85,94 \%)$ sedangkan responden yang memiliki persepsi kurang baik terdapat 9 orang $(14,1 \%)$.

Persepsi adalah cara pandang terhadap sesuatu atau mengutarakan pemahaman hasil olah daya pikir, artinya persepsi berkaitan dengan faktor-faktor eksternal yang di respons melalui panca indra, daya ingat, dan jiwa. Persepsi adalah pengalaman tentang objek, peristiwa, atau hubungan-hubungan yang diperoleh dengan menyimpulkan informasi dan menafsirkan pesan. Pengertian ini memberikan pemahaman bahwa dalam persepsi terdapat pengalaman tertentu yang telah diperoleh individu $^{11}$.

Hasil penelitian ini sejalan dengan penelitian Angelia yang menunjukkan bahwa pada hasil penelitian terdapat 61 responden (66.4\%) yang mempunyai persepsi pelayanan yang diberikan oleh tenaga kesehatan di puskesmas Kumelembuai itu baik dan 31 responden (33.6\%) yang mempunyai persepsi bahwa pelayanan kesehatan yang diberikan oleh tenaga kesehatan di puskesmas Kumelembuai itu kurang baik ${ }^{12}$.

Hasil penelitian ini menggambarkan bahwa sebagian besar pasien di RSUD Jend. Ahmad Yani Metro memiliki persepsi yang baik pada pelayanan keperawatan, dengan demikian maka secara umum masyarakat telah memberikan respon yang positif atau telah memiliki penilaian yang baik pada pelayanan keperawatan yang pada akhirnya masyarakat akan akan cenderung merasa puas dengan pelayanan-pelayanan yang diberikan oleh pihak rumah sakit.

\section{Kepuasan Pasien Pada Pelayanan Keperawatan}

Berdasarkan hasil pengumpulan dan pengolahan data dapat diketahui bahwa dari 64 responden, sebagian besar memiliki merasa puas dengan pelayanan keperawatan di RSUD Jend. Ahmad Yani Metro yaitu sebanyak 44 orang $(68,8 \%)$ sedangkan responden yang kurang puas terdapat 20 orang $(31,2 \%)$.

Kepuasan menurut Kamus Bahasa Indonesia adalah puas; merasa senang; perihal (hal yang bersifat puas, kesenangan, kelegaan dan sebagainya). Kepuasan dapat diartikan sebagai perasaan puas, rasa senang dan kelegaan seseorang karena mengonsumsi suatu produk atau jasa untuk mendapatkan pelayanan suatu jasa. Kepuasan pasien adalah keadaan saat keinginan, harapan dan kebutuhan pasien dapat dipenuhi. Suatu pelayanan dinilai memuaskan bila pelayanan tersebut dapat memenuhi kebutuhan dan harapan pasien. Jadi kepuasan atau ketidakpuasan adalah kesimpulan dari interaksi antara harapan dan pengalaman sesudah memakai jasa atau pelayanan yang diberikan.

Hasil penelitian ini juga sejalan dengan penelitian Angelia yang menunjukkan bahwa terdapat 69 responden $(75 \%)$ merasa puas dengan pelayanan yang diberikan oleh tenaga kesehatan di Puskesmas Kumelembuai dan 23 responden $(25 \%)$ merasa tidak puas dengan pelayanan tenaga kesehatan yang diberikan di Puskesmas Kumelembuai ${ }^{12}$.

Hasil penelitian ini memberikan gambaran bahwa pelayanan keperawatan yang ditujukan untuk mempertahankan kesehatan, meningkatkan kesehatan, menolong klien untuk mengatasi secara tepat masalah yang dihadapinya dengan tujuan untuk mencapai kemandirian klien dalam meningkatkan status kesehatan secara optimal dengan pencegahan sakit dan peningkatan keadaan sehat yang ada di RSUD Jend. Ahmad Yani Metro semakin baik, hal ini dapat dilihat dari tingkat kepuasan pasien dimana sebagian besar pasien merasa puas dengan pelayanan yang diberikan.

\section{Hubungan Persepsi Pasien Pada Pelayanan Keperawatan Terhadap Kepuasan pasien}

Pada hasil uji statistik menggunakan chi square (Fisher's exact test) didapatkan nilai probabilitas $p$-value $=0,022<\alpha 0,05$ maka secara statistik diyakini terdapat hubungan bermakna antara persepsi pasien pada pelayanan keperawatan dengan kepuasan pasien. Pada hasil analisis juga didapatkan nilai Odds Ratio (OR) sebesar 5,857 (CI;95\%: 1,290-26,590), dengan demikian maka pasien yang memiliki persepsi baik tentang pelayanan keperawatan cenderung merasa puas sebesar 5,857 kali lebih besar dibandingkan dengan pasien yang memiliki persepsi kurang baik.

Pelayanan keperawatan merupakan bantuan yang diberikan karena adanya kelemahan fisik dan mental, keterbatasan pengetahuan, serta kurangnya kemauan, untuk melaksanakan kehidupan sehari-hari secara mandiri. Kegiatan dilakukan dalam upaya peningkatan kesehatan, 
pencegahan penyakit, penyembuhan, pemulihan serta pemeliharaan kesehatan dengan penekanan pada upaya pelayanan kesehatan utama (primary health care) sesuai dengan wewenang, tanggungjawab dan etika keperawatan. Kepuasan yang dirasakan oleh pasien dalam pelayanan keperawatan merupakan aspek yang sangat penting bagi kelangsungan suatu rumah sakit. Kepuasan pasien adalah nilai subjektif terhadap kualitas pelayanan yang diberikan. Penilaian subjektif tersebut didasarkan pada pengalaman masa lalu, pendidikan, situasi psikis waktu itu, dan pengaruh lingkungan pada waktu itu.

Hasil penelitian ini juga sejalan dengan penelitian Angelia yang menunjukkan bahwa terdapat $31(36.6 \%)$ pasien yang mempunyai persepsi pelayanan yang diberikan oleh tenaga kesehatan kurang baik, 23 (25\%) pasien diantaranya mempunyai persepsi pelayanan tenaga kesehatan yang kurang baik serta tidak puas dengan pelayanan yang diberikan dan ada 8 $(8.6 \%)$ orang yang mempunyai persepsi pelayanan kesehatan yang diberikan kurang baik tapi mereka merasa puas dengan pelayanan yang diberikan oleh tenaga kesehatan. Sedangkan, ada $7(7.7 \%)$ pasien yang mempunyai persepsi pelayanan tenaga kesehatan baik tapi mereka tidak puas dengan pelayanan yang diberikan oleh tenaga kesehatan dan ada 54(58.7\%) pasien yang mempunyai persepsi pelayanan yang diberikan baik dan mereka puas dengan pelayanan tenaga kesehatan yang diberikan. Berdasarkan hasil uji chis-quare di dapat hubungan yang signifikan antara persepsi pelayanan tenaga kesehatandengan kepuasan pasien karena nilai $\mathrm{p}<0,05$ yaitu $0,000^{4}$.

Hasil penelitian di atas menunjukkan bahwa pasien yang memiliki persepsi baik sebagian besar merasa puas dengan pelayanan keperawatan yaitu sebesar $74,5 \%$, hal ini terjadi karena persepsi merupakan sesuatu yang muncul dari panca indra, baik dari penglihatan maupun pendengaran sehingga pasien yang memiliki persepsi baik dalam menilai suatu perlakuan akan cenderung merasa puas dengan perlakuan tersebut. Pada penelitian ini ditemukan sebesar 25,5\% pasien yang memiliki persepsi baik namun kurang puas dengan pelayanan keperawatan, hal ini dapat terjadi karena pada kondisi-kondisi tertentu pasien sangat mengharapkan pelayanan yang lebih dari apa yang diberikan oleh pihak perawat, tetapi harapan tersebut terkadang tidak sesuai dengan situasi dan kondisi misalnya disaat pasien membutuhkan perawat namun disaat itu pula perawat sedang melayani pasien yang lain, hal inilah yang dapat menyebabkan munculnya sikap kurang puas terhadap pelayanan yang diberikan, padahal di sisi lain tugas perawat bukan hanya melayani satu pasien namun harus melayani pasien diruangan secara menyeluruh. Pada penelitian ini juga ditemukan sebesar 33,3\% pasien yang memiliki persepsi kurang baik namun merasa puas dengan pelayanan keperawatan yang diberikan. Hal ini dapat terjadi karena, munculnya persepsi kurang baik hanya didasarkan atas sikap awal dari pasien saat masuk di ruangan, namun ketika proses keperawatan sudah berlangsung dan kondisi pasien membaik maka kepuasan itu akan muncul.

Berdasarkan uraian hasil penelitian di atas dapat disimpulkan bahwa persepsi pasien secara statistik berhubungan dengan kepuasan pasien dimana pasien yang memiliki persepsi baik tentang pelayanan keperawatan cenderung merasa puas sebesar 5,857 kali lebih besar dibandingkan dengan pasien yang memiliki persepsi kurang baik. Oleh karena itu, pelayanan keperawatan secara menyeluruh sesuai dengan standar pelayanan keperawatan yang ada merupakan faktor yang memunculkan persepsi yang baik dan dapat meningkatkan tingkat kepuasan pasien pada setiap pelayanan keperawatan tersebut. Dengan demikian, maka usaha untuk memuncul persepsi yang baik pada pasien harus dilakukan sejak awal pelayanan perawatan sehingga dapat memunculkan perasaan puas, rasa senang dan kelegaan terhadap pelayanan keperawatan.

\section{Kesimpulan}

1. Persepsi pasien pada pelayanan keperawatan ditemukan sebesar 85,94\% dalam kategori baik dan 14,1\% kurang baik.

2. Kepuasan pasien pada pelayanan keperawatan ditemukan sebesar 68,8\% kategori puas dan $31,2 \%$ kurang puas.

3. Terdapat hubungan bermakna antara persepsi pasien pada pelayanan keperawatan dengan kepuasan pasien $(p$-value $=0,022<\alpha$ 0,05; OR 5,857 (CI;95\%: 1,290-26,590).

\section{Daftar Pustaka}

1. Kuswantoro, dkk, Pengaruh Mutu Pelayanan Keperawatan Terhadap Kepuasan Pasien (Di Ruang Rawat Inap Rumah Sakit Islam Malang), diakses pada 
Januari 2014 dalam web site: http://old.fk.ub.ac.id

2. Depkes RI, Pedoman Uraian Tugas Tenaga Keperawatan di Rumah Sakit. Direktorat Jenderal Pelayanan Medik, Jakarta, 1999

3. Kuswantoro, dkk, Pengaruh Mutu Pelayanan Keperawatan Terhadap Kepuasan Pasien (Di Ruang Rawat Inap Rumah Sakit Islam Malang),

4. Goestsch DL, Davis S. Intruduction to tatal quality, productivity, Competitiveness, Englewood Cliffs,NJ: Prentice Hall International Inch: 1994

5. Levelock C, Wriht L, Manajemen pemasaran jasa, Jakarta; PT Intermasa; 2005

6. Kotler P Manajemen pemasaran: analisis, perencanaan, implementasi dan kontrol, Jakarta: PT Prehallindo; 2001

7. Boller C, Wyss K, Mtasiwa D, Tanner M, Quality and comparison of antenatal care in publik an private providers in the united republic of Tanzania, Bulletin of the word Health Organization, 2003; 81 (2); 116-22

8. Andaleeb SS, Public and private hospital in Bangladesh; service quality and predictors of hospital choice. Healt Policy and Planning 2000; 15 (1); 95-102

9. Baltussen RM.Ye Y, Haddad S, Sauerborn RS, Perceived quality of care of primary health care service in Burkina Faso. Health Policy Planning, 2002, 17; 42-48

10. Doung DV, Binns CW, Lee AH, Hipgrave $\mathrm{DB}$, Measuring client-perceived quality of maternity service in Rural Vietnam, International Journal of Quality Helth Care, 2004; 6; 447- 457

11. Mujib, Persepsi, diakses pada bulan Januari tahun 2014 dalam web site: http://bloginfo.heck.in/persepsi.xhtml , 2013

12. Angelina, Rian, 2012. "Effect Of Total Quality Management, Reward Systems And Organization Commitment To Managerial Performance In Hospital In Pekanbaru", Jurnal FE Universitas Riau 